\title{
THE SOCIAL CONTEXTS OF VERBAL ARTS IN YORUBA INDIGENOUS HEALTHCARE PRACTICES
}

\section{Oladele Caleb Orimoogunje}

This article will give an overview about the social context of Yoruba verbal arts connected with healthcare practices (see http:// www.yorubanation.org/Yoruba.htm). The "context" is described as a state or fact of being advantageous to the purpose to which a thing can be applied, and its manner of "using" or power of "using". Furthermore, it could be regarded as a phenomenon that describes how, when, where, to whom and by whom the verbal arts under question are rendered. Therefore, we shall attempt to discuss the social contexts the verbal arts are used in the Yoruba indigenous healthcare system. The social uses of folklore in healthcare are discussed at three distinct levels: domestic, communal and intercommunal levels.

\section{SOCIAL CONTEXTS OF YORUBA HEALTH-RELATED VERBAL ARTS}

The social contexts of verbal arts in the Yoruba indigenous healthcare delivery system explains where performances of the genres under study are found. This part of the study discusses who performs the verbal arts, and to whom the verbal arts are addressed. We endeavour to give a detailed account of how the verbal arts are utilised among the users. It is pertinent to note that there is no specific spot (venue) set aside for the rendition of the said genres when applied for healthcare practices. Various places that could be used for the performances are individuals' compounds, palaces, groves of divinities, markets, consulting rooms, health centres/hospitals, thick forests/savannah or any convenient public gatherings in a given community. The social contexts of the verbal arts in the Yoruba indigenous health management are discussed at three distinct levels - the domestic, communal and inter-communal. 


\section{DOMESTIC CONTEXT}

The social context of Yoruba verbal arts at the domestic level relate to the performance within the nuclear and extended families. Verbal arts such as orin-iremolekun 'lullabies', oriki 'verbal salutes', ofo 'incantations', ayajo 'myth-like incantations', ebe 'propitiation', iwure 'supplicatory blessings' and iba 'homage' are performed frequently in the homestead to uplift the health condition of the addressees. Every elder among the Yoruba is bound to be conversant with the oriki of his/her lineage and town. Such an elder recites some, if not all of it whenever (most especially in the morning) he/ she is greeted by any of the younger ones. It is wrong of the younger ones to make use of oriki 'verbal salutes' while greeting the elders, hence the proverb Enu agba ni obi tii gbo 'Only the elders can confirm the ripe nature of a kola'. At the metaphorical level, it connotes that only the elders talk on an important issue that relates to tradition. This is repeatedly demonstrated by Olabimtan, in two of his novels, Kekere Ekun (1967) and Ayanmo (1973) where the elders render the oriki to make their younger ones feel elevated, and as well, relieved emotionally. The elders use oriki to boost the morale of the youngers. Likewise, orin-iremolekun 'lullabies' are used among nursing mothers to lull their babies to bed. The excerpt below is a dialectal variant of the one cited in Ogundeji (1991: 98) a typical example of lullabies that have a soothing effect and that can help to make babies sleep sound:

Omo-on mi o akurubetekube.

Omo-on mi o akuru bete kube.

Bi oo ku o maa raso fun o.

Bi oo ku maa rova ok6n.

Ova okan la fi $n$ somo loge.

Omo-on mi akurubetekube.
My little young baby.

My little vibrant baby.

If you live I'll buy you clothes.

If you do not die I'll buy you coral beads.

The slaves I bought will carry you all about.

My little young baby.

The Yoruba believe that little babies understand what people say, though they cannot talk. This belief makes them say sweet things and make promises that can convince the little babies that the world is worth living in. Another cogent reason is that they believe that the little babies, or more appropriately, their inner selves have 
control over their health and their willingness to live. In other words, it is believed that the inner selves of the children hear the good wishes of the nursing mothers and endorse them. The effect of the genre is to make babies sleep sound that contributes immensely to their good health. Also, in the homestead, ofo 'incantations' and ayajo 'myth-like incantations' are used to cure and prevent various diseases among members of the family. In the Yoruba traditional set-up, all minor ailments are treated at home. Only very serious ones are taken to the babalawo or other specialists, where the sick reside while being treated. The following incantation is used in a treatment facility for people troubled with stomach ache:

Alanpete inu,

Alanpete inu,

Alanpete inu,

Alaamu ikun,

Alaamu ikun,

Alaamu ikun,

Ewure dudu abe aka,

Ewure dudu abe aka,

Ewure dudu abe aka,

Ojo lo de lo sa wole,

Ojo lo de lo sa wole,

Ojo lo de lo sa wole,
The flat stomach, The flat stomach, The flat stomach, The lizard in the stomach, The lizard in the stomach, The lizard in the stomach, The black goat in the barn, The black goat in the barn, The black goat in the barn, When it started raining you ran inside for shelter, When it started raining you ran inside for shelter, When it started raining you ran inside for shelter,

Ojo naa waa da ki o fomo Oosa sile, The rain has stopped, so leave the divine child.

Ojo naa waa da ki o fomo Oosa sile, The rain has stopped, so leave the divine child.

Ojo naa waa da ki o fomo Oosa sile, The rain has stopped, so leave the divine child. Ki iwo inu rirun yii fi lavaja sile.

Ki o ma run un mo.
You stomachache, N.N., should be relieved.

You should stop aching him. 
It is strongly believed among the Yoruba that the event alluded to in the above excerpt had once really taken place. To them, the authenticity of the mythical story will make the ailment subside by giving relief to the victim who "protected it from being beaten by rain". They have the notion that the spirit of the ailment will be grateful to its benefactor by leaving immediately. The expected action of the ailment collaborates with the Yoruba adage that goes $A$ ki i foju oloore gungi 'One should not be ungrateful to one's benefactor'. Here, the ailment is personified by imposing the attribute (an act of showing appreciation) of a human being on it.

Iwure 'supplicatory blessing' is used frequently, almost every morning, by the elders of every compound. The enchanter weaves his/ her good wishes into iwure and addresses it to every member of the compound. The same thing applies to ebe 'verbal propitiation'. The Yoruba believe that both iwure and ebe could ward-off disasters, melancholy and all sorts of misfortunes that could be stumbling blocks to the good health of the members of their families.

\section{COMMUNAL CONTEXT}

The use of verbal arts in the Yoruba indigenous healthcare practices extends beyond the domestic context. At the communal level, various groups of performers from different homes of the same community are involved. These various groups use verbal arts for different goals in the community. The groups involved in this context are traditional artists, and nursing mothers in both the indigenous and orthodox health centres.

Among the Yoruba musicians and chanters, the verbal arts related to Yoruba indigenous healthcare delivery system constitute a source of information on Yoruba life. They use verbal arts for dual purposes - to amuse people and to inculcate in them the views of the Yoruba on certain phenomena. These genres are used in such a way as to have an impact on the psyche of their targets. Ayinla Omo Wura ${ }^{1}$ employs ofo 'incantations' in his records. One example is presented below: 
Aake lo ni ke e mo tori mi ke o

Aja lo ni ke e mo tori mi ja

Oko tuntun-n-tuntun lo ni ke e mo forokoro ko mi lorun E je $n$ roju saye [---]
An axe orders you not to raise an alarm on me The magic rattle says you should not attack me

A brand new hoe orders you not to harm me Kindly let me be at peace [---]

The musician is emotionally reassured, believing that the above incantation would get him in the good book of his neighbours. Therefore, he is culturally aware that there would be neither harassment nor embarrassment that could lead to hypertension and migraine. ${ }^{2}$ Some Yoruba contemporary musicians make use of health-related verbal arts such as iba 'homage', iwure 'supplicatory blessings', epe 'verbal curse', oriki 'verbal salutes' in their performances. Such musicians include Fatai Olowonyo, Sikiru Ayinde, Haruna Isola, Yusuf Olatunji (Baba L'Egbaa), Dauda Epo Akara, Adedara Arounralojaoba, Odolaye Aremu, Kasumu Adio and a host of others. Obviously, the traditional chanters play vital roles in the promotion of the use of the Yoruba verbal arts. These include the chanters of $i w i$ egungun, Sango Pipe, Esu-Pipe and rara. The end result of their use is to secure their lives, the idea which is tantamount to health management. Fatai Olowonyo makes use of $i b a$ 'homage' in one of his records thus:

[---] Olatunji iba re Omo Ojurongbe Awa ti juba fara iwaju Komode le juba fun wa [---]
[---] Homage to you, Olatunji, The offspring of Ojuronve We have paid homage to elders So that the younger ones can pay us homage [---]

The artiste above shares with the community where he was brought up the tradition that whoever respects the elders paves the way for his/her own greatness. This notion makes him believe that the law of karma exists and this is binding for every individual. Whatever you sow, you would surely reap. This artiste knows that apart from the retributive justice, in ignoring $i b a$ in one's endeavours, one may not be successful. 
Literary artists (novelists and playwrights) use the verbal arts as tools (via chanters in performances) to satisfy them in the aspect of health-related matters. For instance, the vital role $i b a$ plays in healthcare vocations is displayed by Ogunniran (1972: 27-33). In the novel, Ojelade nearly loses his life for failure to pay due homage in one of his performances of an itinerant masquerade. In his subsequent performances, he pays homage, and he gains emotional stability. This style in the literary art makes the literary/creative works look homely and comprehensive, even to those who are well grounded in the Western culture. There are numerous literary artistes in this category who acknowledge (either knowingly or unknowingly) the use of verbal arts in the field of healthcare practices. $^{3}$

We cannot but discuss the roles of nursing mothers (in their performances of natal songs) in both modern and indigenous communitybased health centres. The nursing mothers go to the indigenous or orthodox health centres every appointed day. The nursing mothers and the expectant mothers come from different homesteads/ compounds and meet in the community-based health centres to contribute their own quota, by performing heath-related songs. Let us examine the following natal songs:

\begin{tabular}{|c|c|}
\hline Oluwa ma je $n$ fobe bimo, & $\begin{array}{l}\text { Lord, may I not have my baby } \\
\text { through a caesarean operation. }\end{array}$ \\
\hline Oluwa ma je $n$ fobe bimo. & $\begin{array}{l}\text { Lord, may I not have my baby } \\
\text { through a caesarean operation. }\end{array}$ \\
\hline Keje & May I not bleed to death. \\
\hline$J e k$ & I should have enough body juices. \\
\hline Olut & $\begin{array}{l}\text { Lord, may I not have my baby } \\
\text { through a caesarean operation. }\end{array}$ \\
\hline
\end{tabular}

The excerpt above really works on the psyche of the enchanter, who is an expectant mother, while rendering the prayerful natal song. She believes that her expected day of delivery is in the hands of Oluwa/Olodumare, the Supreme being among the Yoruba. This belief equips her with courage, thereby erasing the unknown that may lead to other health problems. 


\section{INTER-COMMUNAL CONTEXT}

The use of Yoruba health-related verbal arts at the inter-communal level is extensive and widespread. The inter-communality in the use of health-related genres is the utilisation of the said verbal arts among the inhabitants of various towns and villages. The use encompasses various communities in the Yoruba traditional setting. Various communities go to each other either to consult or partake in the ritual performed during the traditional festivals.

The Yoruba believe that the "power" in their health-related verbal arts such as iwure, iba, oriki, ofo, etc. rendered during the festivals could play a positive role in healing their society of various uncertainties, debilities and neurosis. The itinerant traditional artistes go to neighbouring communities to display their versed knowledge in Yoruba cultural heritage. At performances of this kind, oriki that work on the psyche of the recipients is usually rendered.

The Ifa Priests are also consulted by communities plagued with mental disturbances ${ }^{4}$ to cure the affected ones with the appropriate and adequate verbal arts. E.g, in Ogundele and Yemitan (1970a: 4961), Ologbojigolo leaves his home town for Apa city to give healing assistance to the inhabitants and proffer a solution to their turbulent situation. In another work by Ogundele and Yemitan (1970b: 81-85), Seyida, an Ifa priest, proffers ethno-scientific solutions to the health-related problems of various communities including the city of Ajeji-gbodo-wo. ${ }^{5}$

In conclusion, on the level of social contexts and functions, the members of the Yoruba society are active users of verbal arts. They include the knowledgeable elders, both male and female in their capacity as fathers, mothers, heads of the families, heads of communities, priests, artistes, etc. The heath-related genres are in the society to address situations when someone, a member of the society is sick, when performing general greetings at meetings, during other rituals in the community, and when mothers are caring for their babies. 


\section{Comments}

${ }^{1}$ Ayinla Omo Wura was a traditional musician of Apala music. He died in 1978.

${ }^{2}$ According to Bolander et al. (1995: MD-36) in their work on a medical dictionary, migraine is described as a sudden attack of headache that usually affects vision. It may also cause nausea, vomiting, constipation or diarrhea, resulting from constriction of the cranial arteries affecting one side of the head. Among the Yoruba, migraine is called efori-tuulu. The Yoruba believe that migraine could lead to madness.

3 The literary artists in this category include Thomas (1929); Akintan (1931); Fagunwa (1949a, 1949b, 1950, 1954, 1961); Ogundele (1970a, 1970b); Faleti (1965, 1968b, 1969b, 1972); Ladipo (1970, 1971); Owolabi (1974); Olatunji (1980); Opadotun (1982), etc.

${ }^{4}$ An eye-witness account given to the present author is a good example of how verbal arts in an indigenous healthcare delivery system are used at the inter-communal level. In 1971, an Ifa Priest called Olori-Awo (in AayeEkan Ekiti, in Kwara State) was consulted and later invited to Beleje, a nearby village in Igbindo environs (an ancient town which is 14 kilometres from Ondo town). The Ifa priest instructed the villagers, using ese-Ifa 'Ifa verses' to desert the village for their lives. Thereafter, a certain ritual was performed for the health of the villagers.

${ }^{5}$ Ajeji-o-gbodo-wo 'a town which strangers should not enter or sojourn'.

\section{References}

Abimbola, W. 1968. Ohun Ijinle Enu Ifa Apa kiini. Glasgow: Collins. Adeniji, D. 1982. Ofo Rere.Ibadan: Ibadan University Press.

Agboola, F. 1989. Ojulowo Oriki Ifa Apa Kiini. Lagos: Project Publications Ltd.

Ajayi, B. 1995. The Statistical Study of Literary Style and Its Implication For Yoruba Incantatory Poetry. Oyo Journal of Languages and Applied Linguistics (OJOLAL), Vol. 1, No 2.

Ajayi, B. 1996. Ofo (The Yoruba Incantations): A Text Linguistics Analysis. $\mathrm{Ph}$. D Thesis, University of Ilorin.

Awe, B. 1975. Notes on Oriki and Warfare in Yorubaland. Yoruba Oral Tradition. W. Abimbola (ed.). Ile-Ife: University of Ife.

Babalola, A. 1967. Awon Oriki Orile. Glasgow: Collins.

Beier, U. 1980. Yoruba Myth. London: Cambridge University Press. 
Bolander, D. et al. 1995. The New Webster's Dictionary. New York: Lexicon Publication.

Fabunmi, L. 1972. Ayajo: Ijinle Ohun Ife. Ibadan: Onibon-Oje Press.

Fabunmi, L. 1985. An Anthology of Historical Notes on Ife City. Lagos: John West.

Fagunwa 1949a. Igbo Olodumare. Lagos: Nelson Publishers.

Faleti, A. 1965. Ogun Awitele. Oxford University Press.

Ibie, C. 1992. Ifism: The Complete Works of Orunmila. Lagos: Efehi Ltd. Idowu, B. 1962. Olodumare: God in Yoruba Belief. London: Longman.

Ifie, E. \& Adelugba, D. 1998. African Culture and Mythology. Ibadan: Endtime Publishing House.

Macdonald, A. (ed.) 1980. Chambers Twentieth Century Dictionary. Edinburgh: W. and R. Chambers Ltd .

Ogundele, J. \& Yemitan, O. 1970a. Oju Osupa I. Ibadan: Oxford University Press.

Ogundele, J. \& Yemitan, O. 1970b. Oju Osupa II. Ibadan: Oxford University Press.

Ogunniran, L. 1972. Eegun Alare. Lagos: Macmillan Nigeria Ltd.

Olabimtan, A. 1967. Kekere Ekun. Lagos: Macmillan Nig. Ltd.

Olabimtan, A. 1971. Ofo and Ayajo: Two Categories of Yoruba Incantatory Poetry. M.A. Dissertation, University of Lagos.

Olabimtan, A. 1973. Ayanmo. Lagos: Macmillan Nig. Ltd.

Olabimtan, A. 1975. Iwure Nibi Iyoara Ni Ile Yoruba. Iwe Asa ibile Yoruba. O. Olajubu (ed.). Lagos: Longman.

Owolabi, O. 1974. Ori Ade Kii Sunta. Lagos: Macmillan Nigeria Ltd.

Verger, P. 1976a. The Use of Plants in Yoruba Traditional Medicine and Its Linguistic Approach. Seminar Series. Department of African Languages and Literatures, O. A. U. Ile-Ife.

Verger, P. 1976b. Poisons (Oro) And Antidotes (Ero); Evil Works (Abilu) and Protection (Idaabobo) - Stimulants and Tranquilisers, Money - Wives Children. Seminar Series. Department of African Languages and Literature, O. A. U., Ile- Ife. 